\author{
Herlambang PerdanaWiratraman, Majda El \\ Muhtaj, Ifdhal Kasim \\ Fakultas Hukum Universitas Airlangga. Jl. Airlangga No 4-6 Surabaya. \\ Email:herlambangafh.unair.ac.id
}

\title{
RIGHT TO ACCESS INFORMATION IN DECENTRALIZED INDONESIA: A SOCIO-LEGAL INQUIRY
}

\begin{abstract}
Indonesia is no longer an authoritarian country, and no longer centralized government. Decentralization processes since 1999 has changed local democratization in a wider participation. Nevertheless, the culture of openness and incorrupt have been far from the more ideal situation. Bribery, corruption and unresponsive public services have been continuously and more systematic taking place. In that context, the Government of Indonesia enacted Law No. 14 of 2008 concerning Public Information Openness (KeterbukaanInformasiPublik or called PIO Law), which is implemented since 30 April 2010. The PIO law is believed to contribute to the better decentralization processes and economic-political democratization at local level. Nevertheless, although right to access information was guaranteed by law, but it has been applied in limited process. Such situation actually gives clear evidence that decentralized Indonesia should be questioned, especially in terms of how the right to access information has been applied in a meaningful way after the enactment PIO Law in 2008 and, what the dominant problems in implementing right to access information are. This article will elaborate the norms and practices of PIO Law by using the rule of law point of view.
\end{abstract}

Keywords: Right to Access Information, Decentralization, Rule Of Law And Human Rights

\section{ABSTRAK}

Indonesia sudah tidak menjadi negara yang otoriter lagi, dan pemerintahannya tidak lagi terpusat. Proses desentralisasi sejak 1999 telah merubah demokratisasi lokal kedalam partisipasi yang lebih luas. Namun demikian, 
budaya keterbukaan dan utuh telah jauh dari situasi yang lebihi deal. Penyuapan, korupsidan pelayanan publik yang tidak responsif telah terjadi terus-menerus. Dalam konteks itu, pemerintah indonesia memberlakukan undangundang dari no. 142008 tentang keterbukaan informasi publik (UU Keterbukaan Informasi Publik), yang dilakukan sejak 30 April 2010. UU Keterbukaan Informasi Publik di yakini memberikan andil yang lebih baik dalam proses desentralisasi dan demokratisasi secara politik dan ekonomi di tingkat lokal. Meskipun demikian, walaupun hak untuk akses tersebut di jamin oleh hukum, tetapi ditetapkan dalam proses yang terbatas. Situasi seperti sebenarnya memberikanbukti nyata bahwa desentralisasi di indonesia patut dipertanyakan, terutama dalam hal hak untuk mengakses informasi yang sebenarnya telah diterapkan setelah pemberlakuaan UU Keterbukaan Informasi Publik pada 2008 dan apa saja yang menjadi masalah dominan dalam penerapan UU Keterbukaan Informasi Publik. Artikel ini akan menguraikan norma-norma dan praktek-praktek UU Keterbukaan Informasi Publik dengan menggunakan supremasi hukum sudut pandang.

Kata kunci: Hak Mengakses Informasi, Desentralisasi, Supremasi Hukum, dan Hak Asasi Manusia.

\section{INTRODUCTION}

Indonesia is deemed as a new democratic state which has promoted human rights and freedom in various ways. Several indicators can be mentioned in this context, such as the adoption of human rights into new Constitutional amendment (1999-2002), the formulation 'human rightsfriendly' legislations, decentralizing governance, freer election system, and the stronger guarantee of freedom of expression. A key political configuration which had significantly influenced to local governance system is decentralization policy. Decentralization has been legally designed as democratization processes after more than thirty years of authoritarian regime. This has been perceived as wider participation, strengthening local values and self or autonomous governance. Through Law on Regional Governance in 1999 and then its revision in 2004, the political agenda of decentralization has been secured through laws and its operational regulations. This decentralization process is finally considered to be a promotion for protecting citizen and also possibility controlling any political elite in power. In brief, decentralized Indonesia post Soeharto has incredibly changed to local democratization process.

In such context, the Government of Indonesia enacted Law No. 14 of 2008 concerning Public Information Openness (KeterbukaanInformasiPublik or called PIO Law). This law starts operating two years after the enactment, 30 April 2010. Based on article 3 of PIO Law, the law aims to guarantee citizen rights to know any plan of public policy making, public policy program and process decision making; to push public participation in public policy making, to increase public roles in public policy making and good governance for public institution, to implement transparence, effective, efficient and accountable governance, to know the reason of public policy which influence people's basic needs, to develop science and education, and to increase better quality information and management services for public institution. Since PIO law promotes and strengthens public participation in a more democratic and accountable governance, this law is believed to contribute in the better decentralization processes and economic-political democratization at local level.

Numerous progressive developments through legal system have been adopted in the past of 


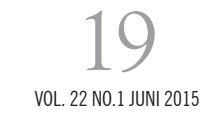

ten years after Soeharto stepped down in 1998. Nevertheless, such developments remain problem in practice. The culture of openness and incorrupt have been far from more ideal situation. Bribery, corruption and unresponsive public services have been continuously and more systematic taking place. Commercialization policy on education and health services, or the development large scale projects without confirming public in appropriate way have often occurred. Poor participation and also 'tokenism participation' (Arstein 1969) showed that although right to access information was guaranteed by law, but it has been applied in limited process.

The relationship between capital ownership and the local ruler became a new and more significant local politic configuration that has influenced political economy of law. It seemed quite often natural resources massive exploitation has marginalized local communities, including destructed social and culture values at local level.

Such situation actually gives clear evidence that decentralized Indonesia should be questioned, especially in terms of how the right to access information has been applied in meaningful way after the enactment PIO Law in 2008, and what problems are dominant in influencing implementation right to access information. This article departs on general overview about the new development in PIO Law, and then analyzing problems in implementing the law, by using socio-legal approach and rule of law perspective, either from procedural and substantial elements of rule of law (Bedner 2010). In order to get deeper information from field level, the field-research for few weeks has been carried out in 7 cities in 5 provinces (Medan and PematangSiantar, North Sumatera; Jakarta; Surabaya and Jember, East Java; Makassar, South Sulawesi; and Mataram, West Nusa Tenggara).

\section{ANALYSIS}

\section{PIO Law and the New Law Development of 'Right to Access Information'}

In this part, it raises a question how has 'right to access information' been guaranteed by Indonesian law system. This is a fundamental question to understand, first, how is right to access information guaranteed normatively, and second, whether such normative provision is adequate for improving right to access information.

\section{A. The PIO Law}

The Government of Indonesia enacted PIO Law in 2008, but this is enforceable after 30 April 2010, precisely 2 years after the enactment. From constitutional point of view, this law is derived from Article 28F of Indonesian Constitution, which stipulates:

"[a]nyone has right to communicate and access to information to develop personal and social environment, also right to seek, obtain, own, save, manage and impart information by using all available channels."

In its consideration, PIO Law states that, (a) any information is basic need for everyone in 


\section{0 \\ JURNAL MEDIA HUKUM}

developing personan and social environment and also important art of national defence; (b) right to obtain information is human rights and public information openness is one of important characters of democratic state which underpin people souvereignity to implement good governance; (c) public information openness is a tool in supporting public monitoring of state public institution governance, and all parts which affect to the public interest; (d) public information management is one of efforts to develop information society.

Those four considerations are the basis of developing public information which very important its role to support democratization process in governace and accountability for the public institution, either government or non-governmental organization. As stipulated at article 3 of PIO Law, the purposes of the law are

a. To guarantee citizen rights to know public policy drafting plan, public policy program, and public decision making process, and also reasoning in making public decision;

b. To push people participation in public decision making process;

c. To improve society roles in making public policy and good governance;

d. To implement good governance, especially transparent, effective, efficient and accountable.

e. To know the reason of public policy which influence basic need of most people;

f. To develop science and englightement nation life; and/or

g. To improve management and information service in Public Agency to produce quality information services.

By having PIO Law, anyone has right to obtain information, especially in the form of

a. Seeing and knowing public information

b. Attending public meeting that openness for public to obtain public information;

c. Obtaining copy of public information through application as prescribed by the Law; and/or

d. Disseminating public information as prescribed by the Law

The purposes and rights as prescribed by PIO Law are deemed as a progressive legal development for improving human rights, especially to promote right to information access. This is also important as stepping stone to advance democracy and human rights in more substantive and protective. Public Institutions have numerous obligations to provide information, as stipulated at article 7 of PIO Law.

Public institution should provide, give and publish public information that accurate, truth, and not fallacy to the 'public information applicant'. Public institutions have to develop information system, so then the public could access effectively, either using electronic or non-electronic tools. These obligations have legal consequences, as stated at article 52-53 of PIO Law,

Article 52: "[p]ublic institution intentionally does not provide, does not give and/or does not publish public information, in the form of periodical information, as public information that must be announced immediately, public information must be available all the times, and/or public information that must be 


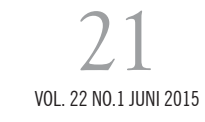

provided as prescribed by the Law, and resulted in a loss to person, subject to a maximum confinement of I (one) year and/or maximum fine of Rp. 5,000,000 (five million rupiahs)."

Article 53: "[a]nyone who intentionally and unlawfully destroy, damage, and/or eliminate public information document in any form of media that is protected by the State and/or related to public interest, subject to a maximum confinement of 2 (two) years and/or maximum fine of Rp. 10,000,000 (ten million rupiahs)."

Interestingly, the PIO Law also requires the government to not only provide information system, but also to appoint Special Officer for Information and Documentation Management (PPID) and to establish Commission of Information (KI) at national, provincial and district level.

PPID is needed to implement a quick, appropriate, and simple information system, especially to storage, to document, to provide and to serve any information of public institution. The establishment of PPID is one of indicators whether or not the public institution is seriously willing to implement PIO Law.

In order to monitor the implementation of PIO Law, the government should establish the Commission of Information (KI). KI is an insdependent body which has obligation to operate PIO Law and its lower regulation, to determine technical standard for public information service and to solve public information dispute through mediation and/or adjudication. In the beginning, the government refused the establishment of KI, but it was widely pushed by civil society to establish an institution to monitor and solve the protection and fulfillment of right to information access in Indonesia. Hence, the public institution could ideally be more accountable and serious in promoting rights, and also could be prevented from any arbitrarily action in providing information request.

\section{B. Mechanism}

According to article 4 of PIO Law, anyone has right to acquire public information as stipulated under the law. Such rights include, to see and to know public information, to attend public meeting that open for public, to receive copy of public information, and to disseminate public information. Beside right to ask information, anyone has right to file the case to the court if somebody has been obstructed and failed in acquiring public information.

Principally, the mechanism to acquire information is based on quick, on time, and cheap. Either written or unwritten application, the public institution should provide written information within 10 (ten) days after such application. The public institution could extend 7 (seven) days in imparting information to the applicant, by explaining the reason and notice.

In case, if the person who applied information to the public institution (PPID), but the PPID does not provide information, does not reply application, replies with inappropriate information, charges improper amount of fee, then he/she can report in written to the upper level of PPID. The upper level of PPID shall inform or reply to applicant within 30 days. 


\section{2 \\ JURNAL MEDIA HUKUM}

If the applicant feels unsatisfy in getting information given by upper level of PPID, then he/ she can apply 'public information dispute' to the KI within 14 days. Then, the KI shall effort in solving the case by mediation or adjudication non-litigation, and it must be processed within 14 days. And finally, KI has to decide the dispute in maximum 100 days.

In sum, the mechanism process of acquiring information will be processed maximum within 171 days, or more than 5 months. This mechanism is actually ineffective in terms of the time, because it is considered as too long. The length of time could be a problem or detrimental if specific required information is needed to solve the urgent cases.

Nevertheless, such mechanism is not the end of process. The public institution or applicant could bring the KI's decision to the court, within 14 days after receining KI's decision. If it is related to state institution, it can be brought to Administrative Court, but if it is related to nonstate institution, it can be filed to District Court. Both of them could be appealed (cassation) to the Supreme Court if necessary. This is also within 14 days. For the Supreme Court, there is no time frame of obligation when the decision of 'public information dispute' can be given.

From this point of view, it can be concluded that the mechanism reflects a very proceduralistic process which could be considered as ineffective in terms of time. Unsurprisingly, it could also possibly lead to a complicated process for the public.

\section{Restrictions}

Although information is principally open for public, but there are several restrictions under PIO Law, especially under the Chapter V of Exempted Information. These public informations are included:

a. Law enforcement, especially judicial process prior the court session;

b. Intelectual property rights and unjust business competition;

c. State defense and security;

d. Natural resources property;

e. National economy defense;

f. Foreign affairs interest;

g. Authentic letter, in relation to private and testament;

h. Personal secrecy;

i. Memorandum or letters between public institutions, or inter-public institution;

j. Other secrecy information as determined by the law.

Although those exempted information are detailed into several sub-provisions, this category is actually unclear, too broad, multi- interpretative, and highly possible subverting right to access information. The list of exempted information might be detrimental for realizing right to access information at several points. First, it might be interpreted arbitrarily, because those articles are easily multi-interpretative. For example, journalist might be limited in doing journalism works, 
especially in searching information, they will face difficulties in gathering information; Second, such articles will affect to the prohibition access of information for journalist to investigate ongoing legal cases, except legal cases that already indicted in the court. In the context of law enforcement, only few cases are closed for public, such as the privacy cases or the cases that involve children. Third, it has criminal sanction if the public unravels those exempted information.

On the other hand, Tuesday, 11 October 2011, the parliament also passed a new law which was closely related to the PIO Law, namely Intelligence Law. Under such intelligence law, there is no detail and specific provision of intelligence secrecy, and ironically those intelligence secrecies are defined as state secrecy. As stipulated under article 25 section (2) of Intelligence Law, intelligence secrecies are in relation to,

a. Dangerous for state defense and security;

b. Expousing natural resources property;

c. Detrimental for national economy defense;

d. Detrimental for foreign affairs politic and international relation interest;

e. Expousing memorandum or secretive letters;

f. Dangerous for state intelligence system;

g. Dangerous for access, agent and resources which are related to intelligence function;

h. Dangerous for state intelligence personnel safety;

i. Expousing planning and operation which are related to intelligence function.

The most serious problem is similar to PIO Law, beside too broad, multi- interpretative, and higly possible subverting right to access information, the Intelligence Law has also heavy criminal punishment.(Article 25-26 junctis 44 of the Intelligence Law 2011). Moreover, Intelligence Law does not provide sub-provisions in explaining those secrecy items. This paper argues similarly to (Fitspatrick, 1998), that "The tension between national security and freedom of expression and information is both acute and multifaceted. Stifling of dissent and secretiveness are the hallmarks of repression."

From this legal point of view, restrictions under PIO Law and Intelligence Law could be subverting or opposing the realization of right to access information. Normatively, right to access information in current Indonesia is regulated by a 'double-sword' law, one is aimed to promote democratization through public participation and guarantee right to access information, on the other hand it could be a weapon to eliminate public rights to know and participate in such democratization process. In this context, the implementation of PIO Law is more influenced by the implementator, especially public institutions or PPID and also the role of KI in monitoring access information system. In other words, the implementation of PIO Law and progressive realization of right to information access are based on 'seriousness and political will' of the public institution at any level, regardless state organization or non-state organization. 


\section{4 \\ JURNAL MEDIA HUKUM}

\section{The PIO Law: Implementation and Its Problems}

As emphasized in the previous part of this article, although the PIO Law is deemed as progressive one, but this is normatively locked by numerous contradictive provisions in substance. Hence, the implementation of the PIO Law much depends on level of seriousness and/or political will of public institution. Unsurprisingly, the implementation of the PIO Law is different between one region to other regions.

Although diverse in practice, generally it can be stated that the implementation of the PIO Law is still very weak. How can this situation be explained in the context of the existing law since four years ago. This elaborates field situation in 7 cities/5 provinces (Medan and PematangSiantar, North Sumatera; Jakarta; Surabaya and Jember, East Java; Makassar, South Sulawesi; and Mataram, West Nusa Tenggara).

\section{Understanding of the PIO Law}

Almost all respondents said that the weak level of understanding of the law is the primary problem in implementing the PIO Law. Although the law was enacted since four years ago, most of government official did not know in detail what the substance of the PIO Law is. Ironically, they did not seriously learn this new law as a part of their responsibilities to implement it.

The critical issue is the government officials do not want to open public documents by stating those are as 'state secrecy'. 'State secrecy' is like a weapon to close information and transparency for public to monitor government policies or bureaucracy works. APBD (Local Budget and Expenditure) for instance, this is often said as 'state secrecy' and hence the parliament member or government officer do not provide any information about APBD. APBD is clear as public document, and it should be opened, not only when the APBD has been agreed by local parliament or district mayor, but also during APBD making process.

In fact, public is still difficult to obtain APBD, because law maker do not understand the new law on right to access information. The weak level of understanding has been influenced by culture of secrecy for long time under authoritarian or undemocratic regime in Indonesia, especially during Soeharto period. The culture of secrecy had been dominantly practiced in favor such regime. Although Soeharto stepped down in 1998, the bureaucracy post Soeharto has not been changed much. Moreover, bureaucracy network at local level has shown a new oligarchy, which preserving old culture or bad governance.

Legalized corruption, bribery tradition, in-transparency and also complicated model of governance are typically governance tradition which still exist and occur in Indonesia post Soeharto.

\section{"Delayed Justice is Denied Justice": Ineffective Mechanism and Execution}

As stipulated in previous part of this paper, according to the PIO Law, the mechanism process of acquiring information will be processed maximum within 171 days, or more than 5 months. This mechanism is actually ineffective in terms of the time, because it is considered as too long. In 


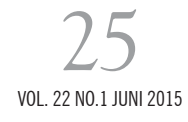

fact, most of information applicants stated that such mechanism is ineffective. Moreover, the KI's decision can be disputed through the court, either administrative court for state public institution and district court for non-state public institution. This is possible as well to appeal through the Supreme Court ('cassation proccess'). It can be imagined that the process in disputing right to access information is highly possible taking very long process and definitely consuming the time.

Ineffective in this context is based on argumentation that access to the information is usually related to their rights, such as right to education, right to health, housing rights, etc. If their rights are not secured and unclear when they hold such rights, including related information for protecting and fulfilling their rights, it can be stated as delayed justice. In this regard, delayed justice is denied justice, clearly unjust for the public.

The problem of 'delayed justice' also potentially occurs after the KI's decision. The problem is related to how the KI's decision is implemented or fulfilled by the public institution. For instance, in its decision, KI asked a particular public institution to open document for applicant, and it is mentioned into certain time. The legal question is how if the public institution still does not want to obey such decision? This is the issue of execution process after decision, because although KI has similar process like the court, but unlike the court system, this institution has no clear execution process. Consequently, several 'public information dispute' cases after having KI's decision are unenforced.

These are not merely legal problems, but also political commitment of public institution to obey and to ensure effective principle in implementing the PIO Law. Without a good political commitment, the loophole of legal stipulation will be played and abused in favor undemocratic governance.

\section{Lack of Political Will}

The most serious and more systematic problem is related to lack of political will. Right to access information as stipulated by the PIO Law is deemed as threaten for those who are in power. Lack of political will in realizing right to access information is easily indicated from several issues.

First, unwillingness to implement the PIO Law mandates. The public institutions do not want to give any access for the public because they want to keep information as secrecy. In the case of DPRD Jember, the parliament members have often rejected the requirement of civil society groups in asking information or public documents, such as APBD. Ironically, they rejected without giving proper reason (KhoerusSholeh, interview, 25 October 2011). If they give reason, this has often argued irrationally, such as pretended to forget or keep quite and foolish (Sudarsono, interview, 22 October and 24 October 2011).

As journalist, AndiSiahaan said that such situation is similar to New Order. Most of public institutions have anti-media attitude. If such situation occurred, then it depends on tenacity of journalist himself, including his network with other journalist or even with officials (AndiSiahaan, interview, 15 September 2011) 


\section{6 \\ JURNAL MEDIA HUKUM}

This perspective is also agreed by Tigor and Rika. The officials often say "I have no authority to answer, please do ask the manager or leader!" (TigorMunthe, interview, 15 September 2011; Rika Yoes, interview, 25 October 2011). Regardless those reasons, generally it can be said that the most problematic is unwillingness. They (public institutions) tend to protect any information, arrogant, and lack of moral accountability (IrwandiLubis, interview, 25 October 2011).

Second, many governmental organizations actually are not ready to develop public information system. Based on field situation, we found two reasons, first, unwillingness to develop public information system; and second, the officials do not have adequate capacity to establish public information system (Abdul Azis, interview, 19 October 2011; A. Latief, interview, 6 October 2011).Both reasons actually intertwined, and it seems that public information system is not deemed as an important agenda for government institutions. Adversely, the government prefers to not do anything about this system, because it would affect to 'their businesses'.

Third, PPID as a responsible person or task force in implementing and serving public in obtaining information are not seriously established, or at least suspended. From all research sites showed that a very limited number of government institutions established PPID. For instance, almost all public institutions at provincial level in South Sulawesi did not prepare and establish PPID, including the Government of South Sulawesi Province. Even, the Internal Affairs Department as national level of public institution that must stand as pilot project for good governance or as an example for other institutions, did not have PPID. "How the other and the lower government institutions will promote right to access information and establish PPID if our central government is not serious to express their good intention?" said AzwarHasan, Chairperson of KI South Sulawesi Province (AzwarHasan, interview, 20 October 2011).This is a fact, PPID as a channel for public and law mandate is not followed up by the public institutions, although the law was enacted since four years ago.

Fourth, as law mandate to establish public information system and PPID, the establishment of $\mathrm{KI}$ is also slow progress and suspended. $\mathrm{KI}$ as a mechanism machinery for implementing the guarantee of right to access information is often opposed by public institutions, especially in the region where the government is not really ready to start new culture of openness and democratization. There have been only 10 of $33 \mathrm{KI}$ at provincial level already established (30 per cent). Moreover, the establishment of KI at District level is also very slow and limited number. For instance in East Java Province, there is only 1 of 35 region where has KI at District level, which is KabupatenBangkalan. In North Sumatera, the recruitment of Provoncial KI's commissioner just has been resulted 15 names to be interviewed. The selection process thorugh parliament in North Sumatera seems very slow and unclear. In response to such situation, at least 40 civil society groups established Massif (civil society concern on information). They hope the provincial KI can be formed as soon as possible (Erwin Manalu, interview, 25 October 2011)

Fifth, without transparency and fair process, the KI institution might be hijacked by politician or political elite interest. The KI as a strategic institution that monitors the implementation of 
right to access information would be important for democratization at various levels. Nevertheless, it would be also seen as threathen for those who are anti-democratization process. To give an illustration, several civil society groups worried about the selection process of KI in Bangkalan District (East Java), because 3 of 5 commissioners are politicians. According to local activist, politician or political party domination could affect to neutrality and proportionality of KI, especially the KI policies in the near future would be influenced and based on political interest, rather than democratization. "I am afraid this new institution will be trapped into political interest!", said Ahmad Muzakki, Chairperson of Brimob, civil society group in Bangkalan(60\% AnggotaKomisiInformasiBangkalan Kader Parpol, 29 June 2011, Okezone.com, <http:// news.okezone.com/read/2011/06/28/340/473791/60-anggota-komisi-informasi-bangkalan-kaderparpol>, retrieved on 3 September 2011).Similar to Muzakki, "We see that KI's institution in Bangkalan is merely designed in favor local elites rather than an agenda for local democratization", said a member of group discussion in Surabaya.Bangkalan's case has given learning example that KI institution must be steadily monitored as well, especially starting since recruitment process of commissioner member. "Without proper dissemination, the selection process of KI's commissioners is driven as particular politics." (Imran Simanjuntak, interview, 15 September 2011)

Sixth, as stated by most respondents, lack of budget is pointed out as the major problem of the weak process in implementing the PIO Law. The government has been always hiding with this reason instead of admitting their lack of commitment in implementing right to access information. The most serious issue in this regard was the current statement of Secretary General for Internal Affairs Ministry, DiahAnggraeni. She said that KI will burden local government budget, especially in establishing and maintaining such institution. Unsurprisingly, such statement has been widely regretted and criticized by KI's commissioners at provincial level. According to AzwarHasan, he regretted Diah's statement because it would make systematic corruption exist, democracy is 'stabbed' and it would weaken reformation and good governance spirit(AzwarHasan, interview, 20 October 2011).Hence, there is possibility to assume that actually the central government did not implement seriously the PIO Law, and this statement might be dangerously replicated by lower government at provincial or district levels. The lack of budget can be also interpreted as lack of political will, because by limiting budget means limiting operational works of KI. In this regard, the establishment of KI must be supported by providing adequate budget in order to progress and to guarantee of right to access information in meaningful ways.

Based on these six points, this paper argues that actually the problem of political will in implementing the PIO Law is still clearly dominant situation. It must be unacceptable since the PIO Law was enacted four years ago, but in fact, this research has seen inparallel situation between the development text and regressive implementation of the text. More ironic situation, beside lack of political will, public institution has also serious problem with their limited capacity to understand and to implement rights. For the public, it is quite detrimental for local democratization, as experienced by Ervin Kaffah in Mataram. Kaffah, as Director of Somasi, anti-corruption activist, said 


\section{8 \\ JURNAL MEDIA HUKUM}

that either journalist or anti-corruption activists have been often facing numerous threathens, such as criminalization on defamation issues. And even, several activists were beaten up, tortured and violated their physic and mental because of their activities in monitoring government policies or works (Ervin Kaffah, interview, 23 June 2010).

Learning form those cases, from the field sites showed that the implementation of the PIO law is too far from ideal situation, particularly the low level of readiness to develop public information system and also establish PPID and KI. Two points should be highlighted in this context. First, the problem of paradigm is necessary to be discussed, especially dealing with how to shift 'conventional paradigm' to 'primary service for people paradigm'. Second, based on paradigm change, the public institution must prepare to design a roadmap in implementing the PIO Law. So far, the process and agenda for securing right to access information has been promoted without roadmap, and unsurprisingly if public, even the public institution officials themselves do not know how they can start their agendas.

These are clearly challenges for pro-democratization movement and supporter to steadily promote human rights, especially right to access information.

\section{E. PIO Law: Challenges and Opportunities for Human Rights}

As stated by Hydenet all, that the sensitivity of governance is related to how the rules of political game are managed, either formal rules or informal rules. In this regard, how deep the influential factors as a background in limiting right to access information, the rules (law) must be operated, so then it shows strict governance in pushing the implementation and aims of such law (Hyden et all, 2004). In implementing right to access information, there are also several challenges and opportunities to improve right to access information to protect and fulfill human rights in Indonesia, especially after the enactment of PIO Law 2008.

\section{The Challenges}

The challenges in implementing right to access information are described into four issues. First, this article put the context of decentralization and its relation to political will, as the fundamental problem in implementing right to access information. Decentralization in Indonesia has been dominantly hijacked by non-democratic local governance. Many local elites have been trapped in corruption system, and most of them have been sent to the jail because their involvement on corruption and bribery activities. The corruption system has involved various actors and networks, either at local government, parliament, and judiciary system, including police. In this context, the corrupt governance would be the opponent for the PIO Law implementation. From fieldwork sites, it has been found that many public institutions did not open their information to the public and always refused the public's proposal to obtain documents. Among journalist, it is quite famous statement, 'more corrupt is more difficult to obtain information'.

Second, as stipulated previously, the PIO Law has mechanism in disputing cases. The prob- 


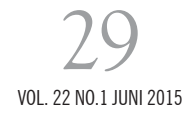

lem is ineffective mechanism, which requires 171 days for solving the legal case if it is brought to KI. Moreover, if it is disputed again into the court, then it would take longer. The challenge in this context is how to make it more effective, so then such mechanism could be fairly used by public or public institution. This discussion includes how the execution process can be obeyed or fulfilled by parties, regardless their position. In the case of one of the parties do not obey the KI's decision, then it must be confirmed as unlawful (onrechtmatigedaad). Denying KI's decision must be considered as violation against the law, and it might be legal consequences which should be discussed further by law maker. The challenge of ineffectiveness in execution was often highlighted by lawyers when they were facing problem in enforcing the KI's decision (LBH Makassar lawyers, 17 October 2011).

Third, disseminating information and participating public in wider perspective are the next challenge in implementing the PIO Law. Either in Medan, Makassar, Mataram, Surabaya, or Jember, most audience said the importance of dissemination processes. Dissemination process, or well known in Indonesia as 'sosialisasi' should be meaningful, not just share information and assume public understand with such information. As informed during research, some said that dissemination could not be done because the lack of budget, but some other argued that dissemination will not be done because the PIO Law is not considered as their priority policy. From the investigation at field, both reasons are actually interrelated. This is because when the government does not provide adequate budget to support dissemination process, at the same time, it means the government does not serious in prioritizing the fulfillment of right to access information. If the dissemination process is lacking, unsurprisingly the public participation is also weak.

Fourth, although decentralization requires local governments act more active in development, in fact, many of them still refer to the role of central government or higher level of government. If the central/higher government does do something, then it will be followed up by local/lower government. In the case of right to access information in Indonesia, the national government has been less effort to give 'best practices' for protecting the rights. This can be stated in responding to the reluctant of Internal Affairs Department in establishing PPID. AzwarHasansaidAzwarHasan (Chairperson of KI South Sulawesi Province), interview, 20 October 2011)

\begin{abstract}
"the local governments in South Sulawesi do not establishing PPID yet simply because the establishment iniative has been influenced by the absence of PPID at Internal Affairs Department and Provincial Government. How the local governments establish PPID if the higher institutions themselves do not seriously develop system and respect the PIO Law?"
\end{abstract}

This situation confirmed that actually the implementation of the PIO Law has been shaped by unserious and unwillingness of the government at various levels, and it has been systematically done to deny rights and democratization processes in the context of decentralized Indonesia.

\title{
Opportunities
}

Beside the challenges, the research has found also several possible points in advancing rights 


\section{0 \\ JURNAL MEDIA HUKUM}

to access information. First, democratization climate in post Soeharto regimes has been growing at local level, although imperfect yet, but the progress development has been adopted. "Democratization sphere" would be an important factor for the public or people in participating in decision making process. For instance, public participation in making local regulation (Peraturan Daerah) could be deemed as civil and political rights development in the context of Indonesia post authoritarian regime. Civil society organizations more freely express their voice, and became a pressure group which is necessary for balancing power relation between state and people. Public participation in law making as democratization sphere is more legalized and institutionalized, although in practice, it showed difficulties and various types in implementing public participation.

Second, although there is still inefficiency issues of KI, the establishment of KI is necessary and deemed as new legal development in Indonesian law system. At least, the establishment of KI is also a legal mechanism which can be applied as new legal-politico arena for public in claiming their right to access information. The question is to what extent the KI may shift inefficiency issues to efficient institution that serves public needs, and the establishment of Provincial/Local KIs at local level can be used to improve performance of the local governance. KI may push government to establish PPID, and also monitor their works to serve public information. KI also can encourage non-state organization to be more transparent and accountable.

We could learn from positive developments in disputing right to access information, such as two KI's decision in Medan, first, information dispute between LAI Sumut (North Sumatera Children Institute) v. SMAN 1 Sunggal; and second, information dispute between 17 candidates of civil servant v. District Major in Medan. According to Nuriyono, Director of LBH Medan, the process of adjudication non-litigation in such cases has been quickly and fairly implemented(Nuriyono, interview, 25 October 2011)

Third, the enactment of the PIO Law could be a 'new weapon' for anti-corruption movement. The movement has been spreading throughout the country, this social movement is seen as potential strategy to promote not only the PIO law as a legal basis of rights to access information, but also democratization and human rights protection for citizen. In short, social movement is quite helpful and useful to implement right to access information.

According to KI's report, the most active organizations on disputing information access thorugh KI have been applied by ICW Jakarta (Indonesian Corruption Watch) and LSM GebrakSumenep (anti-corruption group). ICW has been successful in monitoring and encouraging public widely to develop anti-corruption as a social movement, and inspiring for other civil society groups to do similarly at various levels.

The second most frequent complaints have been applied by LSM Gebrak. LSM Gebrak has complaint for the first time in East Java, against Prosecutor. Information dispute between LSM Gebrak and Sumenep Prosecutor was started from the LSM Gebrak's information request about state financial matters that were taken by the prosecutor, especially after court decision. Such request was not ignored by prosecutor. Then LSM Gebrak sent letter for disputing information 
access at Prosecutor Agency in Sumenep.

According to the Head of Sumenep Prosecutor Agency, Abd.Azis, who stated that his institution actually did not close any information. He said that his institution did not know in detail about information which should be secrecy or opened for public, as mandated by the PIO Law. "I think this is only misunderstood. We principally are never intransparent. Perhaps this was effect of unknown technical issues how to provide information." ${ }^{1 " ~(S e n g k e t a ~ K I P ~ K e j a r i S u m e n e p-L S M ~}$ Gebrak, Pertama di JawaTimur", JawaPos, Thursday, 19/08/2010).

Corruption is the most crucial issue in decentralized Indonesia. From 250 new autonom regions that have been formed, at least 1.800 corruption cases were unraveled and sent to the court process. Most of corruptors in such cases are local elites. Since 2004 to 2009, that was noted that 1.243 local parliament members have been involved and suspected due to their corruption activities. In only a semester of 2010, ICW reported at leats 159 corruption cases have been found. Ironically, the law enforcer seemed unserious and unwilling to enforce corruptor because they were mostly local elites (1.891 KasusKorupsiTerjadi Di Daerah HasilPemekaran: BuktiUrgensiKeterbukaanInformasi Di Daerah, 26/10/2010, KebebasanMemperolehInformasi, <http:/ /www.kebebasaninformasi.org/ver2/detail.php? no_best=81>, visited on 5 August 2011)

Hence, right to access information became more important to support the existing anti-corruption movement.

Fourth, the role of free press that plays as voicing public rights would be helpful and useful. Undoubtedly, many human rights and corruption cases were widely known by public because of the role of the press. Press may support civil society groups by providing clue information through their news. Then, public can take opportunity to obtain further information which are related to their problems.

Quoted from Wiratraman (2010), there are several norm relations between the Press Law (1999) and the PIO Law (2008). First, there is constitutionality relation on freedom of expression, especially between article 28 and 28F of the Constitution. Second, both laws guarantee the relationship between press freedom and right to access information for citizen. Third, both laws are inline to human rights protection, especially civil and political rights. Fourth, norm relationship to push advocacy and to fulfill information based on fundamental needs of the people. And fifth, in journalism practice, the PIO Law completes the Press Law, especially for protecting professional journalistic.

This opportunity actually was also fully understood by either Commisssion of Information (KI) or Press Council, especially to use right to access information for supporting press freedom. KI Chaiperson, Ahmad AlamsyahSaragih, and Press Council Chairperson, Prof. Dr. BagirManan, SH., MCL., have signed memorandum of understanding (MOU). According to article 2 of MOU, the MOU is aimed,

1. To prevent any effort that restrict the implementation of press function and journalistic activities after the enactment of the PIO Law 2008; 


\section{2 \\ JURNAL MEDIA HUKUM}

2. To give certainty, benefit, and justice guarantee for the press in implementing tasks and function in obtaining information access based on Principles of Public Information Openness.

As said by Ahmad AlamsyahSaragih, "Such MOU is expected to guarantee journalist rights in obtaining information, so then procedural aspects in the PIO Law do not disturb journalist works." BagirManan also said that, "MoU is aimed to prevent overlapping among public institutions in relation to press freedom... do not let the press is hampered by the PIO Law." (KomisiInformasiPusatDewanPersTeken Nota Kesepahaman, 15 July 2011, KomisiInformasi RI, <http:// www.komisiinformasi.go.id/index.php/subMenu/informasi/info_and_opini/detailberita/84>, visitedon 16 October 2011)Based on this MOU, we do hope press could play roles significantly in unraveling any information that is important for improving human rights and basic life of the people.

\section{CONCLUSION}

Based on previous research that carried out by ISAI (2008), HRLS (2010) and KontraS (2011), there are several ideas in implementing right to access information by using the PIO Law mechanism.

ISAI recommended four points, first, Depkominfo (Communication and Information Department) should conduct dissemination of the PIO Law; Second, Public institution should develop information unit to serve public. This can be a new institution or developing the existing institution; Third, The government should support 'PPID capacity building'; and Fourth, the government should formulate information system and information service standardIrawanSaptonoet.all (2008) (“SusahnyaMemintaInformasiPublik", 1 September 2008). In order to make an effective implementation, ISAI suggested to the government to design 'a roadmap' in implementing right to access information, otherwise, the implementation might be unclear (IrawanSaptonoet.all,2008)

The problem of right to access information guarantee is not merely the issue of KI's establishment at regional or local level, but also preparing human resources and institutional infrastructure of government in order to be ready in implementing the PIO Law effectively. The challenge is not only the legal instrumentation, but it is more developing 'openness culture' as effort to improve local democratization. Hence, according to HRLS research in 2010, it would result significant changes in progressing local democratization (Wiratraman, HerlambangPerdana, 75: 2010).

Interestingly, in 2011, KontraS also carried out research on right to access information in 7 provinces. Their research was only focused on Police Institution (POLRI). Based on their research, it has been recommended that POLRI has to disseminate internal regulations which are related to the PIO Law, also supervision and internal monitoring for its accountability. Coordination among units in POLRI should be developed, including providing a special mechanism about secrecy review. This is also supported by adequate budget and integrated website, so then POLRI could 
develop publication sphere to communicate with citizen (Kontras, 30: 2011).

Learning from empirical evidence from several cities in this research (June-October 2011), it shows clear evidence that right to access information as mandated by the PIO Law is still far from ideal implementation. The applications of the law, including the role of new institutions, such as $\mathrm{KI}$ and PPID, have been challenged by real situation of non-democratic governance at local level. The corrupt system still rampantly occurred, and it has influenced in blocking any source of information.

This paper argues that, behind the slow progress and low level of awareness, especially those public institutions which are not ready to provide information system and PPID, there is something more serious than the issue of lack of capability of the government official to understand the implementation of the PIO Law. The more serious problem actually is 'lack of accountability and unwillingness'. This occurred systematically throughout the country and Department of Internal Affairs as influential state institution in promoting the PIO Law, seemed keeping silence in promoting right to access information.

Such problem is inseparable from 'political will' of the government at various levels. As mentioned previously in this chapter, there are six dominan problems. First, unwillingness to implement the PIO Law mandates; Second, many governmental organizations actually are not ready to develop public information system, this because either unwillingness to develop public information system or the officials do not have adequate capacity to establish public information system; Third, PPID as a responsible person or task force in implementing and serving public in obtaining information are not seriously established, or at least suspended; Fourth, the establishment of KI is also slow progress and suspended; Fifth, without transparency and fair process, the KI institution might be hijacked by politician or political elite interest. And sixth, lack of budget is also the major problem of the weak process in implementing the PIO Law. The current statement of Secretary General for Internal Affairs Ministry, DiahAnggraeni, who said that KI burdens local government budget, was contradictory in promoting right to access information.

Because of the lack of political will, this paper argues that the establishment of KI is not enough to guarantee right to access information. The KI roles in mediating and adjudicating information dispute might be easily subverted and denied if the political elites could drive the legal process and institution of KI. Moreover, the issue of right to acces information is simply deemed as procedural aspects in obtaining information.

Based on practices at field, right to access information in decentralized Indonesia has to be considered as not only as legal issue, but also political issue. Political issue in this regards refers to the importance such rights to improve quality of democratization processes in Indonesia. The implementation of the PIO Law would be more effective if the ruler put the issue of right to access information as human rights or constitutional rights. As issue of human rights, so then the 'rule of law' issues are inseperable and considered as important factor also in determining whether such rights can be implemented properly. 


\section{4 \\ JURNAL MEDIA HUKUM}

Rather careful in suggesting that the establishment of KI at local level would be useful for public in disputing information cases. It is because the process and recruitment of KI commissioners at local level must be ensured as part of democratization itself. Otherwise, the establishment of KI would be detrimental for the public, because such institution is controlled or at least much influenced by political elite's interest. In short, it would be a legitimed institution in blocking information.

Nevertheless, the most valuable part of the PIO Law is the 'creation of public sphere' to complaint or challenge any public institution to be more democratic, accountable and transparent. Such public sphere could be used as not only disputing information cases, but also as learning for public, including public institutions, in order to fulfil their obligation to protect right to access information. Rika Yoes, a journalist and Chairperson of AJI Medan, said that, 'learning by doing' and 'facing the problems' would be important for public to learn constitutional rights directly from their experiences (Rika Yoes, interview, 25 October2011)

This is an important legal development since the main objective of the law is also to provide equal opportunity for anyone to involve in public decision making. It would open greater possibilities for vulnerable groups, women and children to take part in democratizing local governance. Public is posed on a question, to what extent they could involve, participate and monitor right to access information in decentralized Indonesia. The answer would be public consciousness, that the greater opportunity and more democratic in implementing right to access information might help the realization of human rights in meaningful way and better situation.

\section{REFERENCES}

Arstein, Sherry R. (1969) A Ladder of Citizen Participation.AIP Journal, July 1969.

Bedner, A. W. (2010) "An Elementary Approach to Rule of Law", Hague Journal of Rule of Law, (2)1, 2010, pp. 48-74.

Fitzpatrick, Joan (1998) "Introduction”, in Coliver, Hoffman, Fitspatrick and Bowen (1998) Secrecy and Liberty: National Security, Freedom of Expression, and Access to Information. The Hague: Kluwer.

Hydenet all (2004) Making Sense of Governance: Empirical Evidence from 16 Developing Countries. London: LynneRienner.

KontraS (2011) LaporanPemantauanPelaksanaanKeterbukaanInformasiPublik di Institusi POLRI. Jakarta: KontraS-Tifa.

Memorandum of Understanding (Nota Kesepahaman) between Press Council and Commission of Information concerning on the Implementation of the PIO Law in Supporting Press Freedom, signed on 14 July 2011.

Saptono, Irawan, et.all (2008) "SusahnyaMemintaInformasiPublik", Factsheet Edisi 01, September 2008. Jakarta: ISAI/InstitutStudiArusInformasi.

Saptono, Irawan, et.all (2008) “Tanpa Road Map, Implementasi UU KIP TakJelas”, Factsheet Edisi 
02, September 2008. Jakarta: ISAI/InstitutStudiArusInformasi.

UNDP (1997) Good Governance and Sustainable Human Development: A UNDP Policy Document. New York: UNDP.

Wiratraman, R. HerlambangPerdana (2007) Good Governance and Legal Reform in Indonesia: Human Rights Series. Bangkok: OHRSD Mahidol - Raoul Wallenberg Institute (RWI).

Wiratraman, HerlambangPerdana (2010) "Implementasi UU Persdan UU KIP dalamMendorongDemokratisasiOtonomi Daerah", in Humanitas Journal, PushamUnimed.

60\% AnggotaKomisinformasiBangkalan Kader Parpol, 29 June 2011, Okezone.com, <http:// news.okezone.com/read/2011/06/28/340/473791/60-anggota-komisi-informasi-bangkalankader-parpol>, visited on 3 September 2011.

Sengketa KIP KejariSumenep-LSM Gebrak, Pertama di JawaTimur, Thursday, JawaPos, 19/08/2010.

1.891 KasusKorupsiTerjadi Di Daerah HasilPemekaran: BuktiUrgensiKeterbukaanInformasi Di Daerah, 26 October 2010, KebebasanMemperolehInformasi, <http://www.kebebasaninformasi.org/ ver2/detail.php? no_best=81>, visited on 5 August 2011.

KomisiInformasiPusat-DewanPersTeken Nota Kesepahaman, 15 July 2011, KomisiInformasi RI, <http:/ /www.komisiinformasi.go.id/index.php/subMenu/informasi/info_and_opini/detailberita/ 84>, visitedon 16 October 2011. 